\title{
Cryoprotectants
}

\section{AN INCREASE IN THE VIABILITY OF RAM SPERM WHEN CULTURED IN MODIFIED MEDIUM FOR in vitro FERTILIZATION}

\author{
V.A. BELYAEV', N.A. GVOZDETSKII' ${ }^{1}$, A.A. KANIBOLOTSKAYA', \\ M.P. SEMENENKO ${ }^{2}$, E.V. KUZ'MINOVA ${ }^{2}$
}

\author{
${ }^{1}$ Stavropol State Agrarian University, 12, per. Zootekhnicheskii, Stavrolol, 355017 Russia, e-mail dorohin.2012@in- \\ box.ru (corresponding author); \\ ${ }^{2}$ Krasnodar Research Veterinary Institute, Federal Agency of Scientific Organizations, 1, ul. 1-ya Liniya, Krasnodar, \\ 350004 Russia, e-mail sever291@mail.ru (corresponding author) \\ ORCID: \\ Belyaev V.A. orcid.org/0000-0001-7454-8472 \\ Semenenko M.P. orcid.org/0000-0001-8266-5900 \\ Gvozdetskii N.A. orcid.org/0000-0002-6856-4932

Kanibolotskaya A.A. orcid.org/0000-0003-3003-4175

The authors declare no conflict of interests

Received December 30, 2016

Abstract

Modern livestock necessitates controlled breeding, one of the main methods of which is a long-term preservation of animal reproductive qualities at cell level. In recent years, a considerable progress has been achieved in the development of techniques of animal sperm preparation for in vitro fertilization (IVF). In these, the main purpose is to obtain population of motile sperm with a suitable morphology capable of in vivo or in vitro oocyte fertilization. However, these methods are not always effective because of the lack of standards for the procedure. We first in Russia carried out a study on the viability of ram sperm cultured in the modified IVF medium. The semen was sampled from North Caucasian rams, 2-3 years of age, according to a routine technique, used for sheep and goats' artificial insemination, and domestic State Standards GOST 32222-2013. Sperm was evaluated on organoleptic and microscopic parameters, and cultured for capacitation to render the spermatozoa competent to fertilize an oocyte according to the prototype procedure, described by A.P. Gandhi (2000), and the method, developed by us. In the modified procedure, the sperm is brought to glucose-yolk-citrate diluent (GYC) and then transferred to medium SOF wash, prepared without glucose and supplemented with glutamine with $6 \mathrm{mg} / \mathrm{ml}$ bovine serum albumin, $0.2 \mathrm{mg} \mathrm{ml}$ caffeine and $50 \mathrm{mg} / \mathrm{ml}$ heparin. The developed technique increased the activity of sperm by 1.3 points compared to the commonly used method, the number of live semen increased by $43.7 \%$, their vitality increased 1.6 times and the number of spermatozoa with rectilinear movements was 1.6 times higher. Thus, the developed technique significantly improves ram sperm qualitative and quantitative characteristics and allows us to recommend this method of animal sperm maturation for in vitro fertilization procedure.

Keywords: sperm, capacitation, in vitro fertilization, rams, nutrient media

Key factors of animal productivity are genetic improvement and suitable conditions for phenotypic manifestation of the genetic potential [1]. Reproductive biotechnologies are being improved in Russia for many years [1-4]. There are reports of transplantation [5], producing embryos and the use of thawed semen [6], preparation of bull spermatozoa for in vitro fertilization and increase in their fertilizing capacity [7], morphological evaluation and increase in the boar semen capacitation [8,9]. The experience of foreign researches is based on the recognition of the advisability of in vitro fertilization (IVF) fresh sperm [6, 10, 11].

However, to improve IVF, it is the sperm quality that remains critical. Auxiliary reproductive technologies (ART) include a variety of procedures for separating the most viable germ cells from the seminal plasma for ovum fertilization. The main purpose of these techniques is to obtain a population of mobile spermatozoa with a suitable morphology and ability to fertilize the oocyte in vivo 
or in vitro. In capacitation (maturation, incubation), the movement of spermatozoa changes from regular wave-like to whip-like due to biochemical modifications of cell membrane (a similar process occurs in isthmus) [12]. In the acrosome, the glycoproteins and proteins of the seminal plasma are removed from the plasmalemma, which contributes to the acrosomal reaction $[11,13]$ and allows to remove dead spermatozoa, extraneous cells and their fragments. In vitro capacitation takes place in special media such as Krebs-Ringer and Tyrode, Brinster with high ionic strength, BW, TS-199 with fetal serum (10\%) or bovine serum [14]. The cells are separated in various ways - by once or twice washing the spermatozoa in a culture medium with further centrifugation; by flotation methods (including swim up) based on spermatozoa self-migration or sedimentation; by centrifugation in Percoll density gradient to separate different types of spermatozoa and choose those with appropriate morphofunctional properties, etc. $[5,15]$. Filtration is the least common procedure, but it is worth noting that filtration is only applicable to samples of good quality, and because of the complexity this procedure is not applicable in veterinary $[15,16]$.

Despite the wide arsenal of technologies, the question of which method is most suitable for sperm in vitro processing remains discussible.

The novelty of our research is the development of an improved method for the preparation of ram sperm of for in vitro fertilization. The proposed procedure significantly improves the qualitative and quantitative characteristics of spermatozoa and can be recommended for practical use.

The purpose of this work was to study the viability of ram spermatozoa in a modified medium for in vitro fertilization.

Technique. In the experiment, North Caucasian elite rams $(n=6)$ aged 23 years were sperm donors. The animal weigh ranged from 107.5 to $110.6 \mathrm{~kg}$. The ram sires productivity conformed to the requirements according to the practical guidelines ("Procedure and conditions for evaluation of fine-wool, semifine-wool of meat breeding sheep", Moscow, 2011). Sperm was taken urethrally 2 times a week at 2 day intervals in vivarium, using the artificial vagina (Minitüb $\mathrm{GmbH}$, Germany) as per the descriptions [2, 17].

The samples were evaluated organoleptically and by microscopy (Mikmed2, LOMO, Russia, $\times 100$ magnification) [18]. Light microscopy was carried out in accordance with the WHO guidelines and RF State Standard (GOST 32277-2013) $[15,17]$. Resistance of spermatozoa was assessed according to V.K. Milovanov and A.I. Korotkov as the change in activity in the presence of $\mathrm{NaCl}$. The samples were stained with $10 \%$ nigrosine (OOO TPO Lenpromchem, Russia) and $10 \%$ eosin (OOO Chemical Line, Russia) [17].

As per a prototype-technique that we described earlier [19], fresh ram sperm was kept in a SOF (Synthetic Oviduct Fluide) wash medium without glucose with 4-(2-hydroxyethyl)-1-piperazinethanesulfonic acid (HEPES, pH 6.8$8.2)$, sodium lactate, sodium pyruvate $(0.127 \mathrm{mg} / \mathrm{ml})$ and bovine serum albumin ( $3 \mathrm{mg} / \mathrm{ml}$ ) (OOO Origigio, Russia). To increase the activity and viability of spermatozoa before fertilization, we used the author's technique (hereinafter the developed technique), according to which the sperm was added to a glucosecitrate-yolk diluent (GCY), prepared according to RF State Standard (GOST 14746-69) which contained glucose medical anhydrous (30.0 g), sodium citrate $\mathrm{Na}_{2} \mathrm{C}_{6} \mathrm{H}_{5} \mathrm{O}_{7} \cdot 5.5 \mathrm{H}_{2} \mathrm{O}(14.0 \mathrm{~g})$, egg yolk $(200.0 \mathrm{ml})$, spermosan-3 (750-900 thousand units (ChPUP Gomel Plant of Veterinary Preparations, Belarus), and distilled water $(1000.0 \mathrm{~m}) \mathrm{l}$. Then the sperm was transferred to the SOF wash medium without glucose and glutamine with the addition of bovine serum albumin (6 $\mathrm{mg} / \mathrm{ml})$, caffeine $(0.2 \mathrm{mg} / \mathrm{ml})$ and heparin $(50 \mathrm{~g} / \mathrm{ml})$.

The swim up procedure was performed in the SOF wash and GCY cul- 
ture media using centrifugation at $200 \mathrm{~g}$ for $8 \mathrm{~min}$ (Sigma, USA), after which the samples were placed into the $\mathrm{CO}_{2}$ atmosphere at $37^{\circ} \mathrm{C}$ for 1 hour $\left(\mathrm{CO}_{2}\right.$ incubator, BINDER GmbH, Germany).

The data statistical processing was performed in the Primer of Biostatistic 3.01 program (McGraw-Hill, Inc., USA), using Student's $t$-test. Differences were considered statistically significant for $\mathrm{p}<0.05$. The table shows the mean $(M)$ and standard errors of the mean $(m)$.

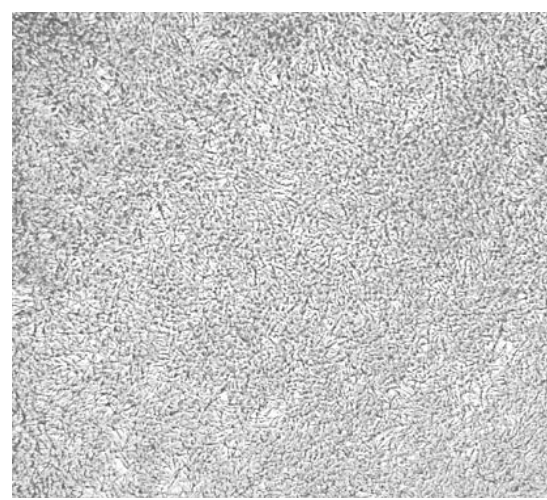

A smear of the North Caucasian ram semen after the swim up procedure when preparing a sample for the improved technology. Description of the groups is given in the Tecnique section. Staining with eosin and nigrosine, $\times 100$ magnification, micrometer Mikmed-2 (LOMO, Russia).

Results. To determine the efficiency of sperm processing by the prototype technique and a modified procedure, we compared the most important spermatozoa indicators (activity, resistance and the number of active spermatozoa with rectilinear motion). Evaluation was carried out before and after the swim up procedure, as a result of which spermatozoa cells were capacitated (Fig., Tables 1, 2).

We found that with SOF wash medium prepared by the prototype method, the activity of spermatozoa before the swim up procedure decreased by $70.9 \%$ compared to normal values, and after the swim up procedure increased by $14.5 \%$. Thus, after spermatozoa maturation in SOF wash medium the activity indices decreased significantly (by $47.6 \%$ at $\mathrm{p}<0.05$ ).

The proportion of spermatozoa with rectilinear motion in fresh sperm placed only in the SOF wash medium decreased by $47.9 \%$ before the swim up procedure and slightly increased (by $11.4 \%$ ) after the swim up, remaining, however, below the approved standards. The ratio of active spermatozoa after swim up was $53.2 \%$ reduced. Since the number of germ cells in the sperm should be at least $80 \%$, low values $(46.8 \%)$ indicated the unsuitability of the sample for fertilization.

1. Some indicators of spermatozoa quality (North Caucasian rams, $n=10, M \pm m$ )

\begin{tabular}{|c|c|c|c|c|c|c|}
\hline \multirow{2}{*}{$\begin{array}{l}\text { Animal } \\
\text { No }\end{array}$} & \multicolumn{3}{|c|}{ SOF wash } & \multicolumn{3}{|c|}{$\mathrm{GCY}+\mathrm{SOF}$ wash } \\
\hline & $\begin{array}{l}\text { activity, } \\
\text { point }\end{array}$ & $\begin{array}{l}\text { active sper- } \\
\text { matozoa, \% }\end{array}$ & $\begin{array}{l}\text { resistance, } \\
\text { thousand units }\end{array}$ & $\begin{array}{l}\text { activity, } \\
\text { point }\end{array}$ & $\begin{array}{l}\text { active sper- } \\
\text { matozoa, \% }\end{array}$ & $\begin{array}{l}\text { resistance, } \\
\text { thousand units }\end{array}$ \\
\hline \multicolumn{7}{|c|}{ B efore swim up } \\
\hline 1 & $5,5 \pm 0,5^{*}$ & $49,8^{*}$ & $18,45 \pm 0,20^{*}$ & $8,9 \pm 0,3^{*}$ & $95,2 *$ & $36,40 \pm 0,20^{*}$ \\
\hline 2 & $5,2 \pm 0,6^{*}$ & $50,7^{*}$ & $16,30 \pm 0,47^{*}$ & $8,9 \pm 0,3^{*}$ & $94,8^{*}$ & $33,24 \pm 0,30^{*}$ \\
\hline 3 & $5,4 \pm 0,5^{*}$ & $51,2 *$ & $15,26 \pm 0,30^{*}$ & $8,9 \pm 0,3^{*}$ & $94,9 *$ & $32,60 \pm 0,46^{*}$ \\
\hline 4 & $5,8 \pm 0,4^{*}$ & $49,0^{*}$ & $14,87 \pm 0,30^{*}$ & $8,9 \pm 0,3^{*}$ & $93,6^{*}$ & $31,59 \pm 0,30^{*}$ \\
\hline 5 & $5,7 \pm 0,5^{*}$ & $48,2^{*}$ & $14,23 \pm 0,40^{*}$ & $8,8 \pm 0,4^{*}$ & $93,7^{*}$ & $34,74 \pm 0,20^{*}$ \\
\hline 6 & $5,4 \pm 0,5^{*}$ & $49,9^{*}$ & $15,60 \pm 0,11^{*}$ & $8,9 \pm 0,3^{*}$ & $93,5^{*}$ & $32,10 \pm 0,12^{*}$ \\
\hline Total & $5,5 \pm 0,5^{*}, * *$ & $49,8^{*}, * *$ & $15,80 \pm 0,30 *, * *$ & $8,9 \pm 0,3^{*}, * *$ & $94,3 *, * *$ & $33,40 \pm 0,30 *, * *$ \\
\hline \multicolumn{7}{|c|}{ After swim up } \\
\hline 1 & $6,6 \pm 0,5^{*}$ & $47,3^{*}$ & $23,10 \pm 0,30 *$ & $8,6 \pm 0,5^{*}$ & $91,3^{*}$ & $31,60 \pm 0,20^{*}$ \\
\hline 2 & $6,2 \pm 0,4^{*}$ & $48,2^{*}$ & $20,30 \pm 0,20^{*}$ & $8,7 \pm 0,4^{*}$ & $91,0^{*}$ & $33,20 \pm 0,20^{*}$ \\
\hline 3 & $6,7 \pm 0,5^{*}$ & $46,6^{*}$ & $19,60 \pm 0,40^{*}$ & $8,9 \pm 0,3^{*}$ & $90,4^{*}$ & $29,30 \pm 0,30^{*}$ \\
\hline 4 & $6,0 \pm 0,5^{*}$ & $46,0^{*}$ & $18,90 \pm 0,30^{*}$ & $8,7 \pm 0,5^{*}$ & $89,9 *$ & $27,90 \pm 0,30^{*}$ \\
\hline 5 & $6,3 \pm 0,5^{*}$ & $45,6^{*}$ & $18,10 \pm 0,30^{*}$ & $8,6 \pm 0,5^{*}$ & $90,0^{*}$ & $31,10 \pm 0,10^{*}$ \\
\hline 6 & $6,0 \pm 0,7^{*}$ & $47,0^{*}$ & $19,60 \pm 0,40^{*}$ & $8,7 \pm 0,5^{*}$ & $90,1^{*}$ & $28,20 \pm 0,20^{*}$ \\
\hline Total & $6,3 \pm 0,5^{*}, * *$ & $46,8^{*}, * *$ & $19,90 \pm 0,30 *, * *$ & $8,7 \pm 0,5^{*}, * *$ & $90,5^{*}, * *$ & $32,20 \pm 0,20 * * *$ \\
\hline
\end{tabular}

N ot e. SOF wash - Synthetic Oviduct Fluide, GCY - glucose-citrate-yolk diluent, swim up - procedure of washing (for more details see the Technique section).

* Differences before and after swim up are statistically significant at $\mathrm{p}<0.05$.

** Differences in the parameters before and after the swim up procedure, carried out according to two methods, are statistically significant at $\mathrm{p}<0.05$.

A standard for spermatozoa resistance should be from 20 to 40 thousand 
units. In our study, this parameter decreased by $54.06 \%$ in the SOF wash diluent, and increased after the swim up by $21.00 \%$ reaching $18.48 \pm 0.20$ to $14.23 \pm 0.40$ thousand units before the capacitation and $18.10 \pm 0.30$ to $23.10 \pm 0.30$ thousand units after the capacitation, but this did not correspond to the normative indicators.

Thus, the SOF wash reduces the viability of sperm and should not be used in processing sperm samples before in vitro fertilization.

2. Percentage of spermatozoa with rectilinear motility (North Caucasian rams, $n=10$ )

\begin{tabular}{|c|c|c|}
\hline Animal No & SOF wash & GCY + SOF wash \\
\hline \multicolumn{3}{|c|}{ B e for e swim up } \\
\hline 1 & 52,4 & 94,7 \\
\hline 2 & 50,5 & 94,0 \\
\hline 3 & 51,8 & 94,2 \\
\hline 4 & 52,9 & 94,1 \\
\hline 5 & 53,0 & 93,7 \\
\hline 6 & 51,6 & 94,2 \\
\hline Total & 52,0 & 94,2 \\
\hline \multicolumn{3}{|c|}{ A ft e $r$ swim up } \\
\hline 1 & $59,4^{*}$ & $92,6^{*}$ \\
\hline 2 & $59,0^{*}$ & $92,9^{*}$ \\
\hline 3 & $60,0^{*}$ & $93,4^{*}$ \\
\hline 4 & $57,9^{*}$ & $92,7^{*}$ \\
\hline 5 & $58,4^{*}$ & $92,5^{*}$ \\
\hline 6 & $57,8^{*}$ & $92,4^{*}$ \\
\hline Total & $58,8^{*}$ & $92,7^{*}$ \\
\hline \multicolumn{3}{|c|}{$\begin{array}{l}\text { Note. SOF wash - Synthetic Oviduct Fluide, } \\
\text { GCY - glucose-citrate-yolk diluent, swim up - } \\
\text { procedure of washing (for more details see the } \\
\text { Technique section). } \\
\text { * Differences before and after swim up are statisti- } \\
\text { cally significant at } \mathrm{p}<0.05 \text {. }\end{array}$} \\
\hline
\end{tabular}

It was found that the index after introduction into the GCY was $5.6 \%$ lower compared to the standard before the swim up procedure and significantly $(\mathrm{p}<0.05)$ decreased by $2.1 \%$ after swim up. In total, sperm processing according to the proposed method reduced activity by $7.7 \%$.

The number of spermatozoa with rectilinear motility in GCY, as compared to the initial values, decreased by $6.2 \%$ before swim up and by $7.9 \%$ after this procedure. The number of active spermatozoa in the sample after introducing an aliquot into the GCY medium significantly decreased by $5.7 \%$ before the swim up, and by additional $9.5 \%$ after the capacitation was compeered. These indicators are within the normative values for the number of active spermatozoa in the sample according to State Standard.

Spermatozoa resistance at the modified capacitation remained within the norm (i.e. decreased by $2.7 \%$ before swim up and by $9.1 \%$ after swim up).

In addition, we described in detail the viability of spermatozoa when applied SOF wash + GCY in norm, before and after the swim up procedure. A comparison of spermatozoa activity suggests that the significant difference between fresh sperm and that processed by the prototype technique is 1.4 points downwards, while in both methods the difference after maturation was 1.3 points. The proportion of spermatozoa with rectilinear motility in the samples prepared according to the developed method was 1.8 times higher before swim up procedure and 1.6 times higher after swim up compared to the samples processed according to the prototype technique. In the SOF wash + GCY media, before swim up, the number of active germ cells was $47.2 \%$ (that is, almost 2 times) more than in the SOF wash. After the flotation procedure in SOF wash + GCY, the number of active cells increased by $43.7 \%$. Before the swim up procedure, the resistance of spermatozoa in the prototype technique was 2.1 times less than when using the developed technique. After the swim up of the spermatozoa in the SOF wash + GCY media, they were 1.6 times more viable than in the SOF wash without GCY.

In reproductive biology, the development of procedures for germ cell maturation and fertilization in vitro is an important fundamental and applied research area [20-22]. Admittedly, the processing of fresh sperm has not received sufficient attention, although this is an important factor in successful fertilization to produce healthy offspring (23). Papers in which the results of a study of the spermatozoa morphology during preparation of rams ejaculate for IVF are presented, are practically absent [24]. Currently, the researchers from 
Stavropol State Agrarian University are the only ones in Russia who developed in vitro fertilization in ewes and the use of frozen-thawed ram sperm which results in embryos successfully produced in vitro. The technique developed for the ram sperm pre-IVF processing significantly improves qualitative and quantitative characteristics of spermatozoa, and, therefore, it may be used in assisted reproductive technologies for in vitro fertilization.

So, we showed that the proposed modification increased spermatozoa activity by 1.3 points compared to the existing technology, while the number of active spermatozoa increased by $43.7 \%$, their viability increased 1.6-fold, and the number of spermatozoa with rectilinear motility was 1.6 times higher, which is associated with a specific effect on the sperm of glucose, sodium citrate and egg yolk. An increase in the qualitative and quantitative characteristics, achieved due to the proposed method, makes it possible to increase the efficiency of in vitro fertilization and the production of healthy offspring.

\section{REFEREN C ES}

1. M g o m e d o v Z.Z. Doklady Rossiiskoi akademii sel'skokhozyaistvennykh nauk, 2008, 3: 42-44 (in Russ.).

2. Ha ns e n P.J. Current and future assisted reproductive technologies for mammalian farm animals. In: Current and future reproductive technologies and world food production. G.C. Lamb, N. DiLorenzo (eds.). Springer New York, 2014, V. 752: 1-22 (doi: 10.1007/978-1-46148887-3_1).

3. Romar R., Funahashi H., Coy P. In vitro fertilization in pigs: New molecules and protocols to consider in the forthcoming years. Theriogenology, 2016, 85(1): 125-134 (doi: 10.1016/j.theriogenology.2015.07.017).

4. Krivoruchko A.Y., Belayev V.A., Kondrat I.Yu., Osipova Yu.S., Met 1 y a e a A.V. Vestnik veterinarii, 2013, 2(65): 50-53 (in Russ.).

5. Trukhachev V.I., Nikitin V.YA., Mikhailyuk V.M., Belugin N.V., $\mathrm{P}$ is a re $\mathrm{nk}$ o N.A., S k r i p k i n V.S. Rossiiskii veterinarnyi zhurnal, 2007, spetsial'nyi vypusk: 35-36 (in Russ.).

6. Trukhachev V.I., Krivoruchko A.Yu., B elyaev V.A., Kvochko A.N., Shakhova V.N. Sposob polucheniya embrionov ovets in vitro. Pat. 2525714 RF, MPK: A01K67/02, A61D19/04 [Sheep embryo production in vitro. Patent 2525714 RF, MPK: A01K67/02, A61D19/04]. Byul. № 23, 2014: 19 (in Russ.).

7. G o 1 u b e t s L.V. Ekstrakorporal'noe oplodotvorenie ootsitov krupnogo rogatogo skota: metodicheskie rekomendatsii [Extracorporeal fertilization of cattle oocytes guidelines]. Grodno, 2010 (in Russ.).

8. Medvedev G.F. Vestnik Belorusskoi gosudarstvennoi sel'skokhozyaistvennoi akademii, 2007, 3: 76-80 (in Russ.).

9. Ganzha A.I., Letkevich L.L., Kostikova I.V. Zootekhnicheskaya nauka Belarusi (Zhodino), 2008, 43(1): 8-15 (in Russ.).

10. M a r i n G.B. An Australasian perspective on the role of reproductive technologies in world food production. In: Current and future reproductive technologies and world food production. G.C. Lamb, N. DiLorenzo (eds.). Springer New York, 2014, V. 752: 181-197 (doi: 10.1007/978-1-4614-8887-3_1).

11. N a 11 e 11 a K.P., S har m a R.K., A z i z N., Ag a rw a 1 A. Significance of sperm characteristics in the evaluation of male infertility. Fertil. Steril., 2006, 85: 629-634 (doi: 10.1016/j.fertnstert.2005.08.024).

12. Guzick D.S., Overstreet J.W., Factor-Litvak P., Brazil C.K., Nakaji $\mathrm{m}$ a S.T., C out if a ris C. Sperm morphology, motility, and concentration in fertile and infertile men. N. Engl. J. Med., 2001, 345: 1388-1393 (doi: 10.1056/NEJMoa003005).

13. A it ke n R.J., B a k e r M.A. The role of proteomics in understanding sperm cell biology. Int. J. Androl., 2008, 31: 295-302 (doi: 10.1111/j.1365-2605.2007.00851.x).

14. St u d e n t s o v A.P. Akusherstvo, ginekologiya i biotekhnika reproduktsii zhivotnykh /Pod redaktsiei V.Ya. Nikitina [Obstetrics, gynecology and biotechnology of animal reproduction. V.Ya. Nikitin (ed.)]. Moscow, 2011 (in Russ.).

15. Vsemirnaya organizatsiya zdravookhraneniya, Mediko-geneticheskii nauchnyi tsentr RAMN. Rukovodstvo VOZ po issledovaniyu $i$ obrabotke eyakulyata cheloveka /Pod redaktsiei L.F. Kurilo [WHO guidelines for human semen analysis and processing. L.F. Kurilo (ed.)]. Zheneva, 2012 (in Russ.).

16. Guimarres A.C., Leivas F.G., Santos F.W., Schwengber E.B., Giot to A.B., Machado C.I., Gonzalves C.G., Folchini N.P., Brum D.S. Reduction of centrifugation force in discontinuous percoll gradients increases in vitro fertilization 
rates without reducing bovine sperm recovery. Anim. Reprod., 2014, 146: 103-110 (doi: 10.1016/j.anireprosci.2014.02.016).

17. GOST 32222-2013. Sredstva vosproizvodstva. Sperma. Metody otbora prob [State Standard GOST 32222-2013. Reproduction. Semen. Methods for sampling]. Moscow, 2014 (in Russ.).

18. L e b o e uf B., De lgadillo J.A., Manfredi E., Pi a cère A., C lé me nt V., M a r ti n P., Pellicer M., B ou é P., D e Cremoux R. Management of goat reproduction and insemination for genetic improvement in France. Reprod. Domest. Anim., 2008, 43: 379-385 (doi: 10.1111/j.1439-0531.2008.01188.x).

19. B elyaev V.A., Krivoruchko A.Y., Shakhova V.N., Gvozdetski N.A., $\mathrm{K}$ a nibolots k a y A.A. Development methods to reduce agglutination of sperm cells in the preparation of freshly sperm to the process for production embryos in vitro. Res. J. Pharm., Biol. Chem. Sci., 2016, 7(5): 893-897.

20. Volpes A., S a m martano F., Rizzari S., Gullo S., Marino A., Allegra A. The pellet swim-up is the best technique for sperm preparation during in vitro fertilization procedures. Assist. Reprod. Genet., 2016, 33(6): 765-770 (doi: 10.1007/s10815-016-0696-2).

21. Wei X., Xiaoling Z., Kai M., Rui W., Jing X., Min G., Zhonghong W., Jianhui T., Xinyu Z., Lei A. Characterization and comparative analyses of transcriptomes for in vivo and in vitro produced peri-implantation conceptuses and endometria from sheep. J. Reprod. Dev., 2016, 62(3): 279-287 (doi: 10.1262/jrd.2015-064).

22. P a r a mio M.T., I z qu i e rdo D. Current status of in vitro embryo production in sheep and goats. Reprod. Domest. Anim., 2014, 49: 37-48 (doi: 10.1111/rda.12334).

23. Lypez-S a u c edo J., S a ntiago-Moreno J., Fierro R., Izquierdo D., Co$10 \mathrm{~m}$ a M.A., C a t a lá M.G., J i m én e z I., P a ra mi o M.T. Fertilization capacity of cryopreserved Iberian ibex epididymal sperm in a heterologous in vitro fertilization assay. Zygote, 2015, 23(1): 136-144 (doi: 10.1017/S0967199413000518).

24. Anzalone D.A., I us o D., Czernik M., Ptak G., Loi P. Plasma membrane and acrosome loss before ICSI is required for sheep embryonic development. J. Assist. Reprod. Genet., 2016, 33(6): 757-763 (doi: 10.1007/s10815-016-0709-1). 